\section{Don't forget health in sustainability talks}

\author{
Many wealthy nations are \\ confronting the health and \\ welfare implications of high \\ unemployment, political \\ instability and eroding social \\ Anthony J. McMichael, Colin \\ D. Butler National Centre for \\ Epidemiology and Population \\ Health, Australian National \\ University, Australia.
} security. Such crises are part of our failure to move sustainability beyond rhetoric - a fact not adequately recognized by the Group of Eight (G8) community. The Rio+20 meeting in Brazil next week must accept that sustainable development and the health of populations depend on each other.

Peak global health may already be here. Low- and middle-income populations endure a double burden from communicable and non-communicable diseases, while health inequity and undernutrition persist. Social and ecological factors such as climate change, energy and food insecurity, counterfeit drugs, antimicrobial and insecticide resistance and poverty all undermine health in our interconnected world.

Many development specialists suggest that health has had its opportunity through the United Nations' Millennium Development Goals, and that the strategic imperative must shift to agriculture or energy. But these are only two legs of the stool: health remains the third.

When sustainability becomes a reality, it will reduce many risks to health. For example, clean energy will eliminate the need to clear forests and use crops for biofuel, so people will be better fed. Improved agricultural practices will reduce exposure to the animal-to-human infections that are associated with land clearing. A green revolution will protect biodiversity by producing more food on land that is already cleared. Better economic, educational and social opportunities in rural areas will slow migration and alleviate the pressure on overloaded urban health resources.
Bianca Brijnath Monash University, Australia. bianca.brijnath@monash.edu

\section{US policy should not shape collaborations} Research Council (GRC) to improve international scientific collaboration (Nature 485, 427; 2012) have been enthusiastically endorsed by John Holdren, director of the White House Office of Science and Technology Policy, and Subra Suresh, head of the US National Science Foundation (see go.nature.com/rbiykb). We disagree with their statement that "good science anywhere in the world is good for science - and good for people everywhere in the world".

The agreed GRC standards for merit-based peer review will improve research quality through collaborations between high- and middle-income countries, which have strong research systems. But the guidelines are unlikely to boost science capacity in lowincome countries.

Holdren and Suresh point out that US researchers could lose global funding if other governments do not review US proposals on their merit, and that the country's economic interests could be harmed if colleagues do not respect confidentiality and intellectual property. Subsequently, the heads of publicly funded science agencies from 47 countries agreed on the GRC's Statement of Principles for Scientific Merit Review.

It therefore seems that the GRC standards are transposing concern about intellectual property to the arena of peer review. This is reminiscent of the linking of intellectualproperty rights with world trade
The aims of the Global law, which has created barriers to drug access in low-income countries.

Instead of implementing an aspect of US foreign policy that is intended to protect US economic interests, the GRC should promote scientific research in low-income countries. Apart from implying that they will discuss the expansion of open-access publishing in these countries, GRC members seem to have paid little attention to this issue.

Bridget Pratt, Bebe Loff Monash University, Australia. bridget.pratt@monash.edu

\section{Planetary boundaries concept is valuable}

As researchers studying the concept of setting environmental boundaries for planetary well-being (J. Rockström et al. Ecol. Soc. 14, 32; 2009), we disagree with Simon Lewis's suggestion that there are flaws in these proposals (Nature 485, 417; 2012).

Lewis contends that the concept's focus is too narrow, that it doesn't distinguish between 'boundaries' and 'thresholds' and that it should clarify the influence of scale on different problems. These are misunderstandings.

Planetary boundaries are not fixed 'supply limits', but are set within a safety margin around complex thresholds that are intertwined at regional and global scales. Ecosystem changes caused by nitrogen pollution, for example, are driven by global trade and cannot be uncoupled from climate change and alterations in land use. Also, investment in new phosphorus technologies can address the problems of both pollution and stock control.

It is a mistake to see the setting of environmental boundaries as a call for multilateral negotiations around static limits. They are instead a bid to reform environmental governance at multiple scales. Scientific assessment, institutional interaction and social-ecological innovation will enable us to work more effectively towards planetary stewardship. Victor Galaz ${ }^{\star}$ Stockholm Resilience Centre, Stockholm University, Sweden.victor.galaz@ stockholmresilience.su.se ${ }^{\star}$ On behalf of 4 co-authors (for a full list, see go.nature.com/uct6dd).

\section{Combat the effects of Forest Code changes}

On 25 May, Brazil's President Dilma Rousseff endorsed revisions to the country's Forest Code. Thanks partly to an appeal from the international scientific community and nongovernmental organizations, together with a petition of more than 2 million signatures, Rousseff also vetoed some of the code's provisions. But more is needed.

The revised code will continue to protect forests in crucial locations, such as along rivers, on hilltops and in coastal wetlands, as well as a specified percentage of those on private property (see go.nature.com/fzxmj5). There will be no amnesty for offenders who illegally logged forests in the past.

I believe, however, that policies to reduce deforestation and foster sustainable development need to be strengthened to counter any potentially adverse effects of the new Forest Code. Payments for ecosystem services must be increased - for example, to expand the important work of the Forest Conservation Allowance Programme (Bolsa Floresta) in the Amazon. Ranching, agriculture and other economic activities should be confined to existing deforested areas. Environmental laws need stricter enforcement, and regular monitoring of forest areas is a priority.

Alison G. Nazareno Federal University of Santa Catarina, Florianópolis, Brazil. alison_nazareno@yahoo.com.br 